\title{
The role of climate and emission changes in future air quality over southern Canada and northern Mexico
}

\author{
E. Tagaris ${ }^{1}$, K.-J. Liao ${ }^{1}$, K. Manomaiphiboon ${ }^{1, *}$, S. He ${ }^{2}$, J.-H. Woo ${ }^{2, * *}$, P. Amar ${ }^{2}$, and A. G. Russell ${ }^{1}$ \\ ${ }^{1}$ School of Civil and Environmental Engineering, Georgia Institute of Technology, 311 Ferst Drive, Atlanta, GA 30332, USA \\ ${ }^{2}$ Northeast States for Coordinated Air Use Management (NESCAUM), 101 Merrimac Street, 10th Floor Boston, \\ MA 02114, USA \\ *current address: Joint Graduate School of Energy and Environment, King Mongkut's University of Technology Thonburi, \\ Bangkok, Thailand \\ ** current address: Department of Advanced Technology Fusion, Konkuk University, Seoul, Korea
}

Received: 13 November 2007 - Published in Atmos. Chem. Phys. Discuss.: 18 February 2008

Revised: 3 June 2008 - Accepted: 10 June 2008 - Published: 24 July 2008

\begin{abstract}
Potential impacts of global climate and emissions changes on regional air quality over southern (western and eastern) Canada and northern Mexico are examined by comparing future summers' (i.e., 2049-2051) average regional $\mathrm{O}_{3}$ and $\mathrm{PM}_{2.5}$ concentrations with historic concentrations (i.e., 2000-2002 summers). Air quality modeling was conducted using CMAQ and meteorology downscaled from the GISS-GCM using MM5. Emissions for North America are found using US EPA, Mexican and Canadian inventories and projected emissions following CAIR and IPCC A1B emissions scenario. Higher temperatures for all sub-regions and regional changes in mixing height, insolation and precipitation are forecast in the 2049-2051 period. Future emissions are calculated to be lower over both Canadian subregions, but higher over northern Mexico. Global climate change, alone, is predicted to affect $\mathrm{PM}_{2.5}$ concentrations more than $\mathrm{O}_{3}$ for the projections used in this study: average daily maximum eight (8) hour $\mathrm{O}_{3}\left(\mathrm{M}^{2} \mathrm{hO}_{3}\right)$ concentrations are estimated to be slightly different in all examined subregions while average $\mathrm{PM}_{2.5}$ concentrations are estimated to be higher over both Canadian sub-regions ( $8 \%$ over western and 3\% over eastern) but $11 \%$ lower over northern Mexico. More days are forecast where $\mathrm{M} \mathrm{hO} \mathrm{H}_{3}$ concentrations are over $75 \mathrm{ppb}$ in all examined sub-regions but the number of days where $\mathrm{PM}_{2.5}$ concentration will be over $15 \mu \mathrm{g} / \mathrm{m}^{3}$ is projected higher only over western Canada. Climate change combined with the projected emissions lead to greater change in pollutant concentrations: average $\mathrm{M} 8 \mathrm{hO}_{3}$ concentrations
\end{abstract}

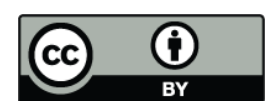

Correspondence to: A. G. Russell (ted.russell@ce.gatech.edu) are simulated to be $6 \%$ lower over western Canada and $8 \%$ lower over eastern Canada while average $\mathrm{PM}_{2.5}$ concentrations are simulated to be $5 \%$ lower over western Canada and $11 \%$ lower over eastern Canada. Although future emissions over northern Mexico are projected higher, pollutant concentrations are simulated to be lower due to US emissions reductions. Global climate change combined with the projected emissions will decrease average $\mathrm{M}_{8 \mathrm{hO}} 4 \%$ and $\mathrm{PM}_{2.5} 17 \%$ over northern Mexico. Significant reductions in the number of days where $\mathrm{M} 8 \mathrm{hO}_{3}$ concentrations are over $75 \mathrm{ppb}$ and $\mathrm{PM}_{2.5}$ concentration over $15 \mu \mathrm{g} / \mathrm{m}^{3}$ are also projected with a significant reduction in peak values.

\section{Introduction}

Global climate and emissions changes are critical factors for future air quality. Although climate change impacts on regional air quality have been examined to some degree (e.g. Mickley et al., 2004; Hogrefe et al., 2004; Knowlton et al., 2004; Murazaki and Hess, 2006; Langner et al., 2005) and have been summarized by Tagaris et al. (2007) there are limited studies examining the effect of long term emission changes on air quality. Dentener et al. (2006) recently compared the global atmospheric environment for the years 2000 and 2030 using global atmospheric chemistry models and different emissions scenarios. The different emissions scenarios result in different global and regional ozone levels. Dentener et al. (2006) found that climate change alone seems to play a minor role although other studies (e.g., Hogrefe et al., 2004) estimate a significant change in ozone level due to climate change. Tagaris et al. (2007) examined the impacts

Published by Copernicus Publications on behalf of the European Geosciences Union. 
of global climate and emissions changes on regional ozone and fine particulate matter concentrations over the United States. They found that the impacts of climate change alone on regional air quality over US are small compared to the impacts from emission control-related reductions, although increases in pollutant concentrations due to stagnation events are found.

Most of the aforementioned studies focus on the US. However, it is equally important to investigate the impact of the climate and emissions changes to the border US regions, given that a large part of Mexican and Canadian population lives there and will both affect and be affected by pollutant transport. These border regions are some of the most dynamic regions of North America in economic, environmental, demographic and cultural terms. Extending the study by Tagaris et al. (2007), the impacts of global climate and emissions changes on regional air quality over northern Mexico and southern Canada are assessed. Future $\mathrm{O}_{3}$ and $\mathrm{PM}_{2.5}$ concentrations for northern Mexico and southern Canada are compared to historic ones under two different cases: i) the impacts of changes on regional air quality by climate change alone are examined by keeping emissions sources, activity levels and controls constant, and ii) the future pollutant concentrations are estimated based on changes in both climate and emissions using the IPCC A1B emission scenarios (IPCC, 2000) and planned controls. This is the first study examining the impacts of climate and emissions changes in these regions and how changes in future US air quality will affect the neighbor countries.

\section{Methods}

Following the same methodology as described in details by Tagaris et al. (2007), and summarized below, we use the Goddard Institute of Space Studies (GISS) II' (Rind et al., 1999) global results downscaled using the Penn State/NCAR Mesoscale Model (MM5) (Grell et al., 1994), forecast North American emissions and the Community Multiscale Air Quality model (CMAQ) (Binkowski and Roselle, 2003) to simulate historic and future air quality. The primary difference between this study and the former is that improved emissions became available for Canada and Mexico.

The Environment Canada's 2000 inventory has been used for area and mobile Canadian sources (http://www.epa.gov/ $\mathrm{ttn} / \mathrm{chief} /$ net/canada.html). For point sources, the 2002 inventory that the New York State Department of Environmental Conservation compiled using the Canadian National Pollution Release Inventory (NPRI) was scaled using Environment Canada's state level summary. For Mexico, the US EPA's 1999 Big Bend Regional Aerosol and Visibility Observational (BRAVO) Study Emissions Inventory was updated with the Mexico National Emissions Inventory (NEI) (http://www.epa.gov/ttn/chief/net/mexico.html). The 2001 Clean Air Interstate Rule (CAIR) emission inventory is used for the US for the early 21 st century, as well as the basis for projected emissions up to 2020 (Woo et al., 2006, 2007). Far future (2020-2050) projections of emissions are carried out based on the Netherlands Environmental Assessment Agency's Integrated Model to Assess the Global Environment (IMAGE). IMAGE uses widely accepted scenarios (i.e., Intergovernmental Panel on Climate Change (IPCC) Special Report on Emissions Scenarios (SRES)) which are consistent with the scenario IPCC-A1B and the climate/meteorological modeling used here.

Meteorological fields are derived from the GISS GCM II', which was applied at a horizontal resolution of $4^{\circ}$ latitude by $5^{\circ}$ longitude to simulate current and future climate at global scale (Mickley et al., 2004). The simulation followed the IPCC-A1B emission scenario (IPCC, 2000) for greenhouse gases. Leung and Gustafson (2005) downscaled the GISS simulations for 1995-2005 and 2045-2055 using the Penn State/NCAR Mesoscale Model (MM5) to the regional scale; no data assimilation has been used. Although there are uncertainties in using regionally downscaled climate in air quality simulations, this approach is necessary in air quality models that employ higher resolution meteorological fields produced by regional instead of global climate models (Gustafson and Leung, 2007). CMAQ with SAPRC-99 chemical mechanism is used for the regional air quality modeling. $\mathrm{O}_{3}$ and $\mathrm{PM}_{2.5}$ concentrations for three historic (2000-2002) summer (June-July-August) episodes are compared to three future (2049-2051) summer episodes. Regional concentrations are predicted for northern Mexico and western and eastern Canada (Fig. 1). To quantify the net impact of climate change and the impact of climate change combined with projected emissions, both the historic period and future cases are examined. Future cases are: i) using the 2001 emissions inventory for historic and future years to quantify the impact of climate change on air quality, and ii) using future forecast emissions along with forecast climate to simulate future pollutant levels over northern Mexico and western and eastern Canada allowing the quantification of both impacts on future air quality.

\section{Results and discussion}

\subsection{Meteorology}

Statistics and spatial distributions for forecast temperature, mixing height, insolation and precipitation for northern Mexico and western and eastern Canada (Table 1 and Fig. 2) show higher average temperatures for the projections used in this study. Northern Mexico is simulated to be the sub-region with the greatest average temperature increase $(2.6 \mathrm{~K})$. The average temperature is calculated $1.7 \mathrm{~K}$ and $1.5 \mathrm{~K}$ higher in western and eastern Canada, respectively. Locally changes up to $4 \mathrm{~K}$ in the northern Mexico and up to $3 \mathrm{~K}$ for Canada are forecast. The mixing heights are simulated to be higher in 
Table 1. Regional average climatic parameters for the three historic and future summers and standard deviation $*(1 \sigma)$ of the summer average.

\begin{tabular}{lllllllll}
\hline & \multicolumn{3}{c}{ Temperature $(\mathrm{K})$} & \multicolumn{2}{c}{ Mixing height $(\mathrm{m})$} & \multicolumn{2}{c}{ Insolation $\left(\mathrm{Watt} / \mathrm{m}^{2}\right)$} & \multicolumn{2}{c}{ Daily Precipitation $(\mathrm{mm})$} \\
\hline & Historic & Future & Historic & Future & Historic & Future & Historic & Future \\
Western Canada & $287 \pm 0.2$ & $289 \pm 1.2$ & $867 \pm 6$ & $838 \pm 33$ & $188 \pm 4$ & $180 \pm 16$ & $2.1 \pm 0.3$ & $2.0 \pm 0.4$ \\
Eastern Canada & $288 \pm 0.6$ & $289 \pm 1.1$ & $919 \pm 41$ & $885 \pm 57$ & $169 \pm 7$ & $158 \pm 9$ & $2.5 \pm 0.4$ & $2.5 \pm 0.3$ \\
Northern Mexico & $296 \pm 0.6$ & $299 \pm 0.1$ & $1035 \pm 59$ & $1062 \pm 36$ & $282 \pm 10$ & $286 \pm 8$ & $1.9 \pm 0.8$ & $2.2 \pm 0.4$ \\
\hline
\end{tabular}

$* \sigma=\sqrt{\frac{1}{N-1} \sum_{i=1}^{N}\left(X_{i}-\bar{X}\right)}, \mathrm{N}=3, \mathrm{X}_{i}$ stands for the regionally averaged summer value and $\bar{X}$ is the three summer average value.

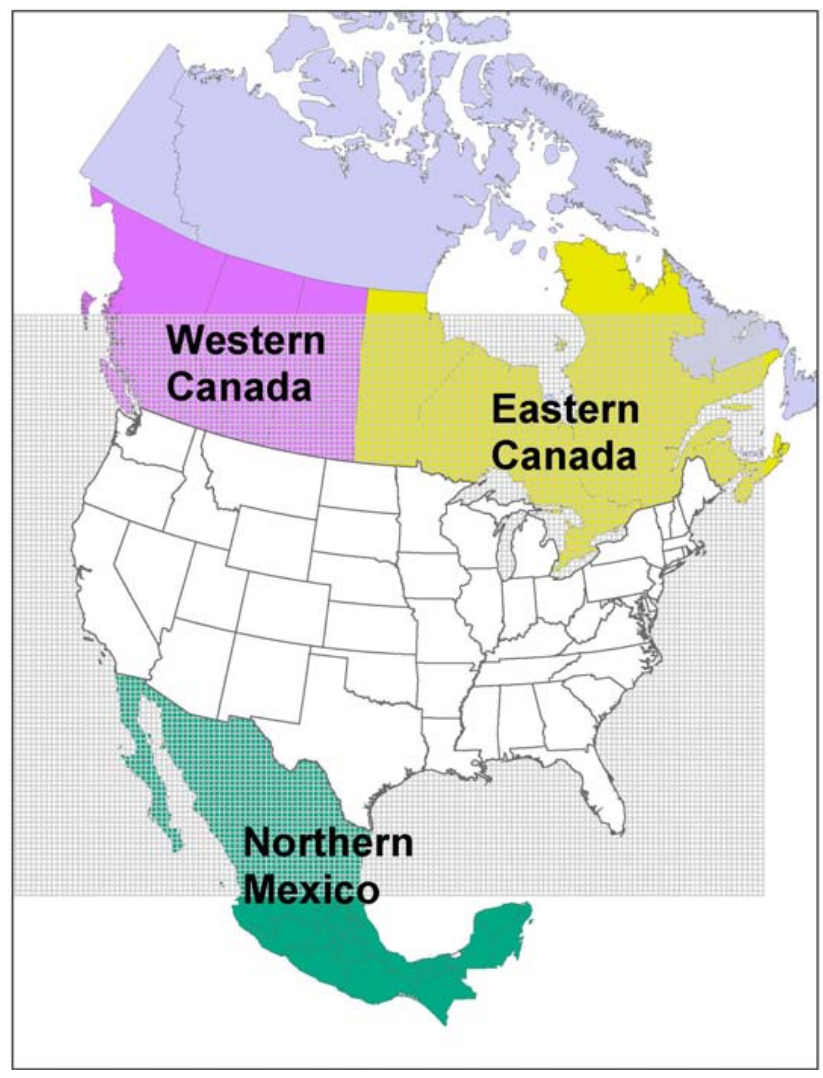

Fig. 1. Modeling domain and regions examined.

most of the northern Mexico (average around $+30 \mathrm{~m}$ ). Maximum increases (around $200 \mathrm{~m}$ ) are forecast near the US border where the maximum temperature increase is also estimated. For both the Canadian sub-regions mixing height is calculated to be lower in the majority of the domain (average around $-30 \mathrm{~m}$ ) except the central part where a small increase is estimated. The average insolation at the earth's surface decreases by $10 \mathrm{Wm}^{-2}$ in Canada and increases by $4 \mathrm{Wm}^{-2}$ in Mexico. Insolation is simulated to be lower in most of the Canadian sub-regions except the central part,

\section{Rainy days: Future summers - Historic summers}

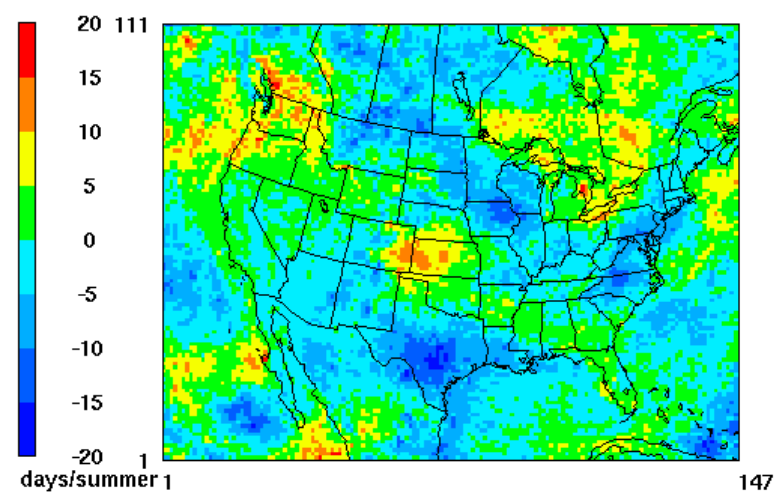

Fig. 2. Spatial distribution plot for the change in rainy days between the three historic and future summers.

while regional changes are expected in the northern Mexico. Regional changes in daily precipitation are forecast with more precipitation in northern Mexico where the average daily change is up to $6 \mathrm{~mm}$ locally. Little change is expected for both Canadian sub-regions. Fewer rainy days (i.e., daily precipitation is more than $1 / 4 \mathrm{~mm}$ ) are estimated for the majority of the northern Mexican and western Canadian subregions in contrast to eastern Canada for which more rainy days are predicted (Fig. 2). Regional average temperature, mixing height and insolation have small interannual variability compared to precipitation (Table 1). All the mentioned local changes in climatic conditions will affect the future local pollutant concentrations.

\subsection{Emissions}

Control strategies applied on anthropogenic Canadian sources result in significantly lower $\mathrm{NO}_{\mathrm{x}}, \mathrm{SO}_{2}$ and $\mathrm{NH}_{3}$ emissions in both Canadian sub-regions (Table 2) for the projections used in this study. $\mathrm{NO}_{\mathrm{x}}$ emissions are projected to be $32 \%$ and $50 \%$ lower in western and eastern Canada respectively while $\mathrm{SO}_{2}$ emissions are projected to be $64 \%$ and 


\section{Temp: Future summers - Historic summers}

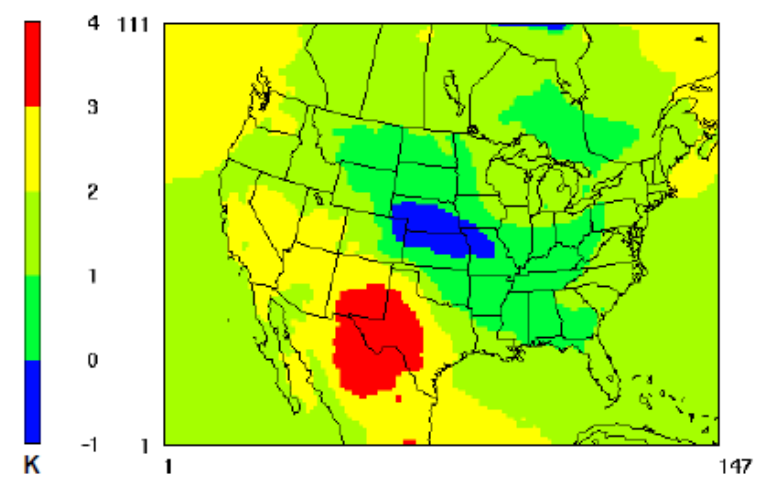

(a)

\section{PBL: Future summers - Historic summers}

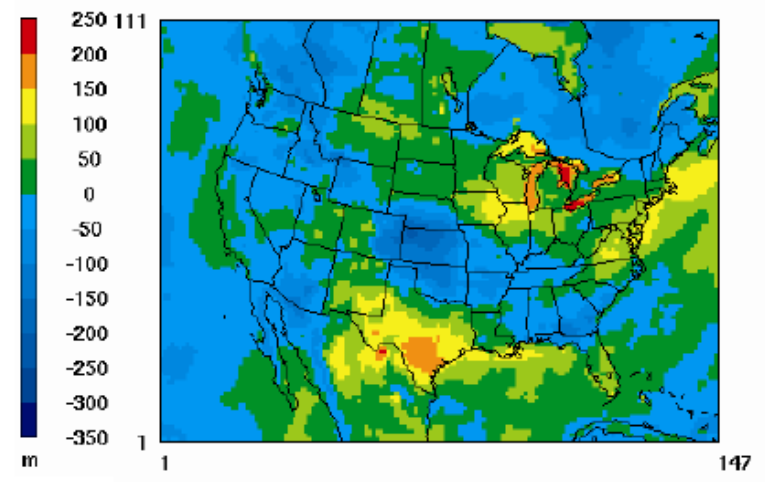

(b)

Insolation: Future summers - Historic summers

Precip.: Future summers - Historic summers

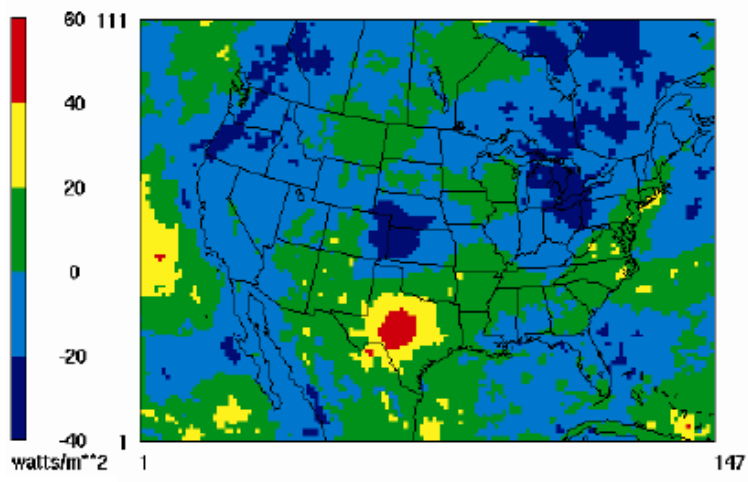

(c)

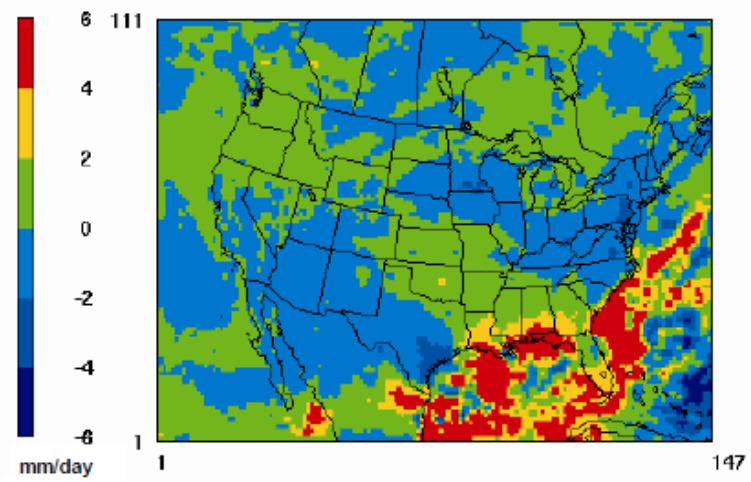

(d)

Fig. 2. Continued. Spatial distribution plots of the average changes in climatic parameters between the three historic and future summers (a) temperature, (b) planetary boundary level (PBL height), (c) insolation, (d) precipitation.

Table 2. Regional average emissions rates (tons/day/grid cell) for historic and future summers using emissions projection (Future) and no emissions projection (Future_np*) and the relative change (\%) based on the historic emissions. np: 2001 emission inventory and 2050 meteorology

\begin{tabular}{|c|c|c|c|c|c|c|c|c|c|c|c|c|}
\hline & \multicolumn{3}{|c|}{$\mathrm{NO}_{\mathrm{x}}$} & \multicolumn{3}{|c|}{$\mathrm{SO}_{2}$} & \multicolumn{3}{|c|}{ VOCs } & \multicolumn{3}{|c|}{$\mathrm{NH}_{3}$} \\
\hline & Historic & Future & Future_np & Historic & Future & Future_np & Historic & Future & Future_np & Historic & Future & Future_np \\
\hline Western Canada & 3.68 & $\begin{array}{l}2.49 \\
(-32.4 \%)\end{array}$ & $\begin{array}{l}3.72 \\
(1.0 \%)\end{array}$ & 1.84 & $\begin{array}{l}0.67 \\
(-63.9 \%)\end{array}$ & $\begin{array}{l}1.84 \\
(0.0 \%)\end{array}$ & 23.11 & $\begin{array}{l}24.49 \\
(5.6 \%)\end{array}$ & $\begin{array}{l}27.50 \\
(19.0 \%)\end{array}$ & 0.92 & $\begin{array}{l}0.65 \\
(-29.6 \%)\end{array}$ & $\begin{array}{l}0.92 \\
(0.0 \%)\end{array}$ \\
\hline Eastern Canada & 1.82 & $\begin{array}{l}0.92 \\
(-49.8 \%)\end{array}$ & $\begin{array}{l}1.84 \\
(0.6 \%)\end{array}$ & 1.58 & $\begin{array}{l}0.41 \\
(-74.2 \%)\end{array}$ & $\begin{array}{l}1.58 \\
(0.0 \%)\end{array}$ & 21.97 & $\begin{array}{l}24.10 \\
(9.7 \%)\end{array}$ & $\begin{array}{l}25.12 \\
(14.4 \%)\end{array}$ & 0.38 & $\begin{array}{l}0.16 \\
(-59.2 \%)\end{array}$ & $\begin{array}{l}0.38 \\
(0.0 \%)\end{array}$ \\
\hline Northern Mexico & 2.32 & $\begin{array}{l}4.60 \\
(98.8 \%)\end{array}$ & $\begin{array}{l}2.39 \\
(3.1 \%)\end{array}$ & 1.88 & $\begin{array}{l}3.53 \\
(87.5 \%)\end{array}$ & $\begin{array}{l}1.88 \\
(0.0 \%)\end{array}$ & 29.61 & $\begin{array}{l}36.81 \\
(24.3 \%)\end{array}$ & $\begin{array}{l}36.78 \\
(24.2 \%)\end{array}$ & 1.22 & $\begin{array}{l}3.89 \\
(218.9 \%)\end{array}$ & $\begin{array}{l}1.22 \\
(0.0 \%)\end{array}$ \\
\hline
\end{tabular}




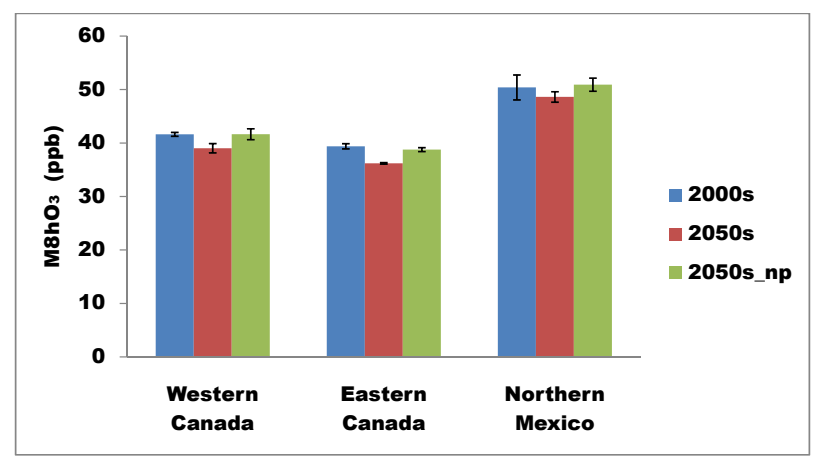

(a)

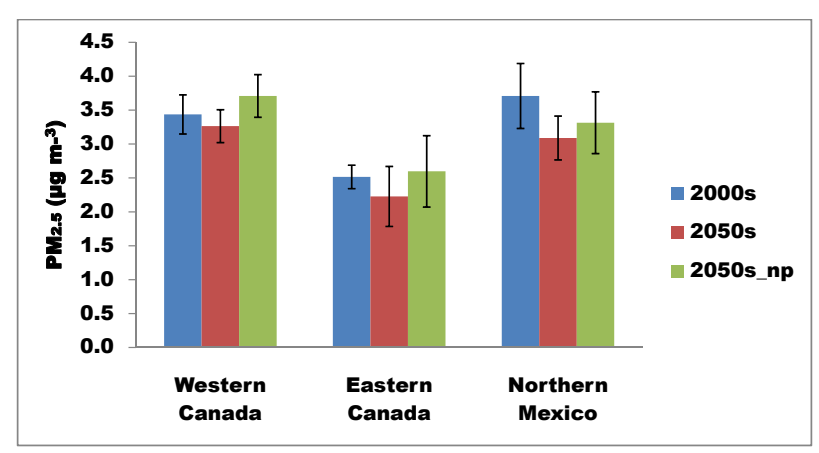

(b)

Fig. 3. (a) Mean maximum $8 \mathrm{~h}$ ozone concentrations $\left(\mathrm{M} 8 \mathrm{hO}_{3}\right)$ and standard deviations for historic and future summers (b) Mean daily $\mathrm{PM}_{2.5}$ concentrations and standard deviations for historic and future summers.

(np: 2001 emission inventory and 2050 meteorology)

$74 \%$ lower in both areas, respectively. $\mathrm{NH}_{3}$ emissions are projected to be $30 \%$ and $60 \%$ lower in western and eastern Canada respectively. Emissions reduction of anthropogenic VOCs combined with the higher biogenic emissions in the warmer climate results in a small change in VOC emissions: $6 \%$ higher in the western Canada and 10\% higher in the eastern Canada.

For the case where only climatic changes are considered, although the emission inventory is kept the same, emissions are not, since some pollutant emissions (e.g., biogenic and mobile) depend on meteorology. A minor increase in $\mathrm{NO}_{\mathrm{x}}$ emissions in both Canadian sub-regions is calculated but VOC emissions will be higher in the future (up to $19 \%$ in western Canada) due to climate change alone (Table 2).

For Mexico, the growth of the industrial sector leads to significantly higher emissions (Table 2). $\mathrm{NO}_{\mathrm{x}}, \mathrm{SO}_{2}$, VOCs and $\mathrm{NH}_{3}$ emissions are projected to be $99 \%, 88 \%$, $24 \%$ and $220 \%$ higher in the future summers in the northern Mexico. For the case where only climatic changes are considered a minor increase in $\mathrm{NO}_{\mathrm{x}}$ emissions is calculated. VOC emissions are projected to be much higher in the future due to climate change alone (around
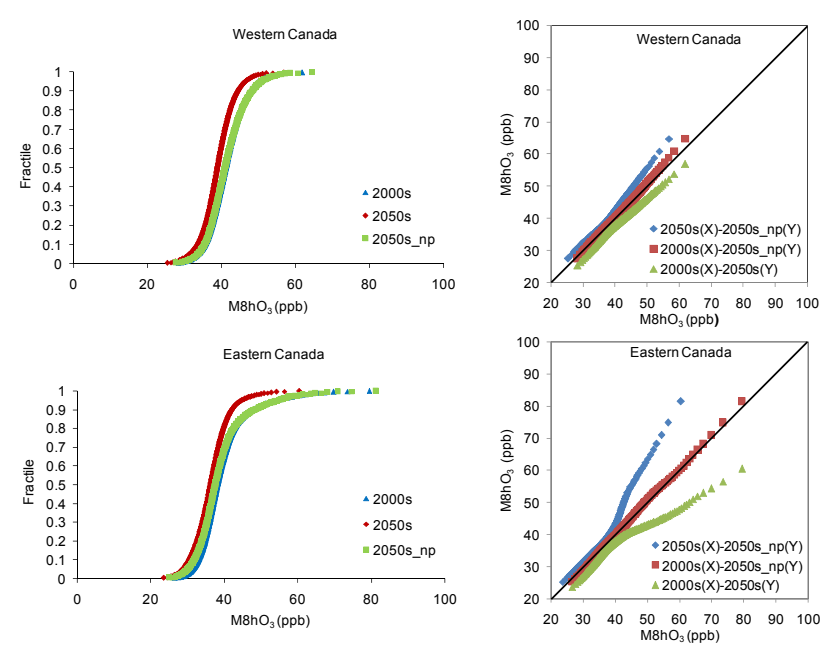

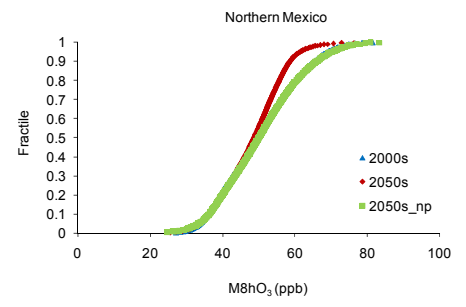

(a)

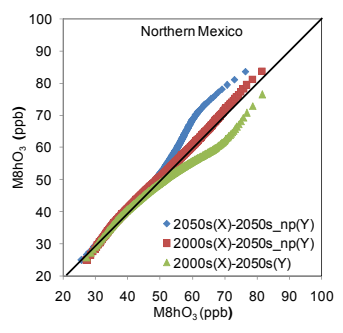

(b)
Fig. 4. Daily maximum $8 \mathrm{~h}$ ozone concentration cumulative distribution function (CDF) plots (a) for historic and future summers and the correlation (b) between the different examined cases. (np: 2001 emission inventory and 2050 meteorology)

Table 3. Observed and predicted daily maximum eight (8) hour ozone $\left(\mathrm{M} 8 \mathrm{hO}_{3}\right)$ and daily $\mathrm{PM}_{2.5}$ average concentrations for the historic summers (2000-2002) and the standard deviations $(1 \sigma)$ of the daily values.

\begin{tabular}{|c|c|c|c|c|}
\hline & & & Observed & Predicted \\
\hline \multirow{3}{*}{ Western Canada } & \multirow{2}{*}{$\mathrm{M} 8 \mathrm{hO}_{3}(\mathrm{ppb})$} & All data & $31.2 \pm 11.3$ & $46.6 \pm 8.8$ \\
\hline & & $>35 \mathrm{ppb}$ & $43.9 \pm 7.5$ & $45.6 \pm 6.7$ \\
\hline & $\mathrm{PM}_{2.5}\left(\mu \mathrm{g} / \mathrm{m}^{3}\right)$ & All data & $5.3 \pm 4.2$ & $5.9 \pm 3.9$ \\
\hline \multirow{3}{*}{ Eastern Canada } & \multirow{2}{*}{$\mathrm{M}_{8 \mathrm{hO}}(\mathrm{ppb})$} & All data & $39.5 \pm 16.3$ & $47.0 \pm 11.6$ \\
\hline & & $>35 \mathrm{ppb}$ & $50.9 \pm 14.0$ & $49.6 \pm 11.8$ \\
\hline & $\mathrm{PM}_{2.5}\left(\mu \mathrm{g} / \mathrm{m}^{3}\right)$ & All data & $10.4 \pm 8.8$ & $7.1 \pm 5.6$ \\
\hline
\end{tabular}

$24 \%$ ), but slightly lower when emissions projection is used caused by the higher projected VOC emissions by human activities. Spatial distribution plots of emissions rate changes for the historic and future summers are presented in auxiliary materials http://www.atmos-chem-phys.net/8/ 3973/2008/acp-8-3973-2008-supplement.pdf. 
Table 4. Regional average $\mathrm{M} \mathrm{hO}_{3}$ and $\mathrm{PM}_{2.5}$ concentrations ${ }^{\mathrm{a}}$ and $\mathrm{PM}_{2.5}$ composition for the historic and future summers using emissions projection (Future) and no emissions projection (Future_np*) and the relative change (\%) based on the historic emissions.

np: 2001 emission inventory and 2050 meteorology

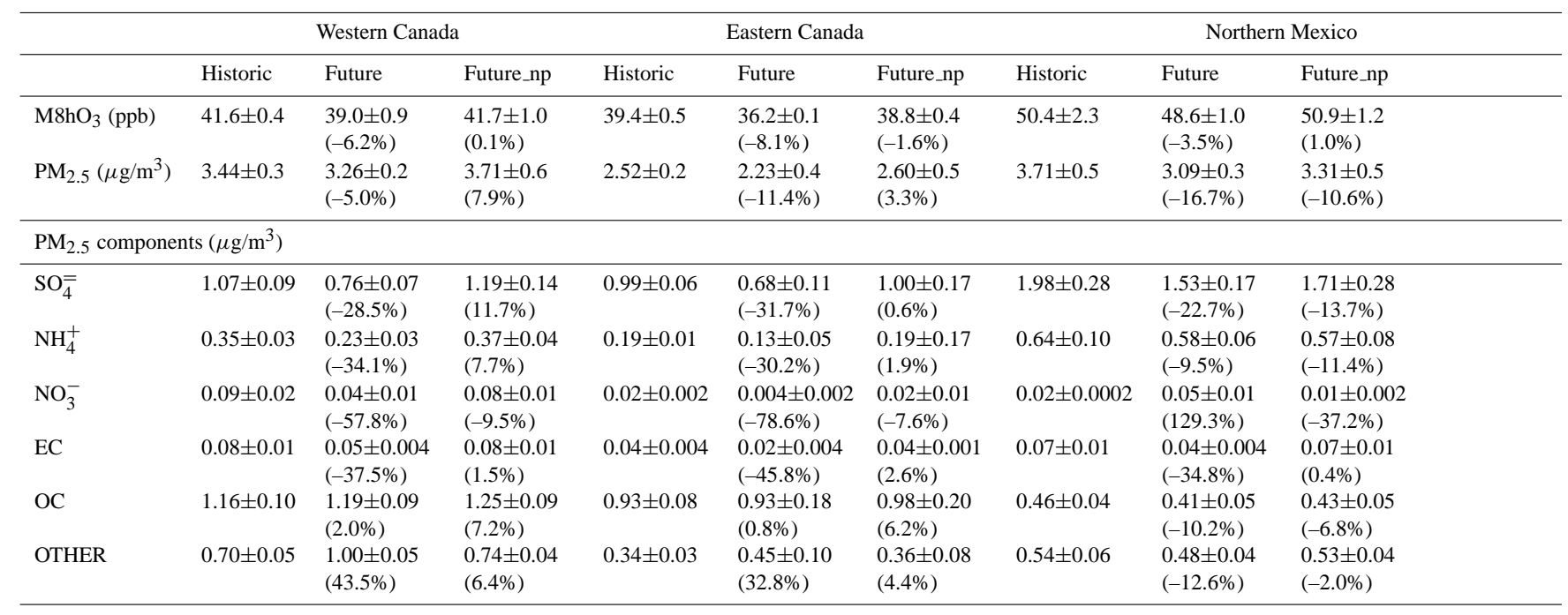

a standard deviation $(1 \sigma)$ is defined in Table 1

Table 5. Number of days per region where $\mathrm{M} 8 \mathrm{hO}_{3}$ concentrations exceed the new standard of 75 ppb and the daily $\mathrm{PM}_{2.5}$ average concentration is higher than $15 \mu \mathrm{g} / \mathrm{m}^{3}$ as well as the peak estimated concentrations for the historic and future summers using emissions projection (Future) and no emissions projection (Future_np*).

np: 2001 emission inventory and 2050 meteorology

\begin{tabular}{|c|c|c|c|c|c|c|c|c|c|c|c|c|c|c|}
\hline & & & \multicolumn{4}{|c|}{ Historic years } & \multicolumn{4}{|c|}{ Future years } & \multicolumn{4}{|c|}{ Future_np years } \\
\hline & & & 2000 & 2001 & 2002 & Average & 2049 & 2050 & 2051 & Average & 2049 & 2050 & 2051 & Average \\
\hline \multirow{4}{*}{ Western Canada } & \multirow[b]{2}{*}{$\mathrm{M} 8 \mathrm{hO}_{3}$} & $\#$ days $>75 \mathrm{ppb}$ & 1 & 33 & 12 & 15 & 0 & 4 & 4 & 3 & 4 & 65 & 51 & 40 \\
\hline & & Peak Value (ppb) & 75 & 88 & 81 & 81 & 67 & 81 & 81 & 76 & 78 & 92 & 95 & 88 \\
\hline & \multirow{2}{*}{$\mathrm{PM}_{2.5}$} & $\#$ days $>15 \mu \mathrm{g} / \mathrm{m}^{3}$ & 290 & 97 & 120 & 169 & 42 & 92 & 36 & 57 & 203 & 387 & 167 & 252 \\
\hline & & Peak Value $\left(\mu \mathrm{g} / \mathrm{m}^{3}\right)$ & 35 & 26 & 26 & 29 & 22 & 22 & 21 & 22 & 29 & 31 & 30 & 30 \\
\hline \multirow{4}{*}{ Eastern Canada } & \multirow{2}{*}{$\mathrm{M} 8 \mathrm{hO}_{3}$} & $\#$ days $>75 \mathrm{ppb}$ & 1469 & 658 & 678 & 935 & 3 & 1 & 101 & 35 & 487 & 505 & 2177 & 1056 \\
\hline & & Peak Value (ppb) & 138 & 108 & 109 & 118 & 77 & 77 & 90 & 81 & 108 & 125 & 132 & 122 \\
\hline & \multirow{2}{*}{$\mathrm{PM}_{2.5}$} & $\#$ days $>15 \mu \mathrm{g} / \mathrm{m}^{3}$ & 1046 & 817 & 1498 & 1120 & 25 & 347 & 62 & 145 & 440 & 1567 & 684 & 897 \\
\hline & & Peak Value $\left(\mu \mathrm{g} / \mathrm{m}^{3}\right)$ & 45 & 44 & 42 & 44 & 23 & 28 & 22 & 24 & 28 & 46 & 36 & 37 \\
\hline \multirow{4}{*}{ Northern Mexico } & \multirow{2}{*}{$\mathrm{M} 8 \mathrm{hO}_{3}$} & $\#$ days $>75 \mathrm{ppb}$ & 2058 & 1484 & 108 & 1217 & 263 & 559 & 155 & 326 & 1912 & 2708 & 1233 & 1951 \\
\hline & & Peak Value (ppb) & 115 & 100 & 98 & 104 & 96 & 94 & 97 & 96 & 107 & 109 & 94 & 104 \\
\hline & \multirow[b]{2}{*}{$\mathrm{PM}_{2.5}$} & $\#$ days $>15 \mu \mathrm{g} / \mathrm{m}^{3}$ & 379 & 432 & 231 & 347 & 0 & 4 & 0 & 1 & 55 & 234 & 71 & 120 \\
\hline & & Peak Value $\left(\mu \mathrm{g} / \mathrm{m}^{3}\right)$ & 27 & 25 & 29 & 27 & 14 & 16 & 14 & 14 & 20 & 24 & 20 & 21 \\
\hline
\end{tabular}




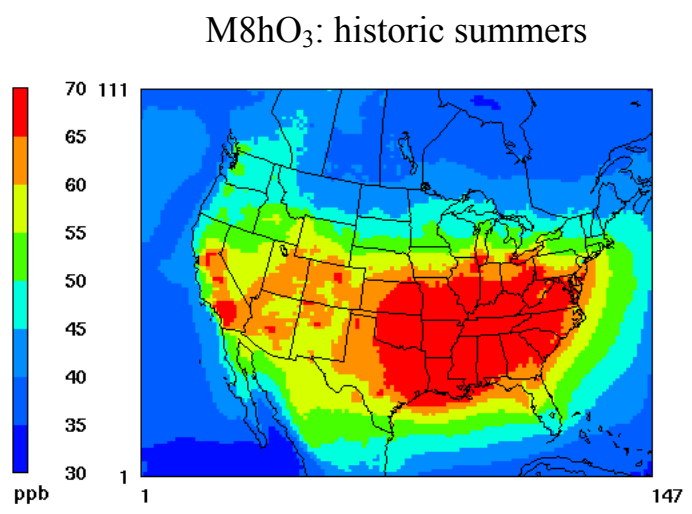

(a)

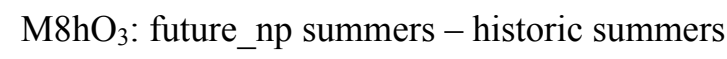

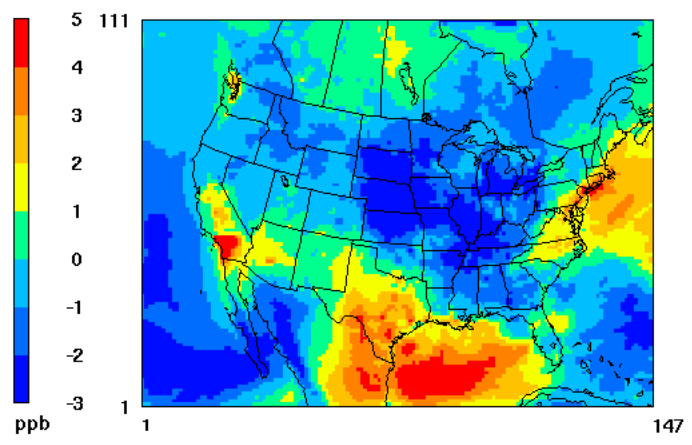

(c)

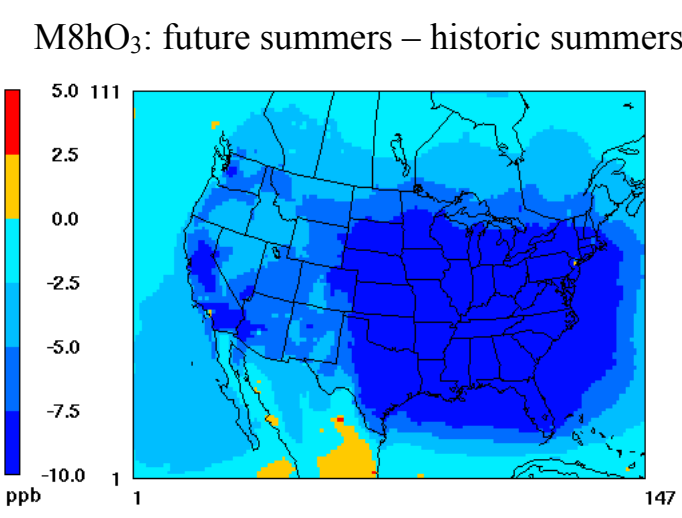

(b)

\begin{abstract}
$\mathrm{M} 8 \mathrm{hO}_{3}$ : future summers - future_np summers
\end{abstract}

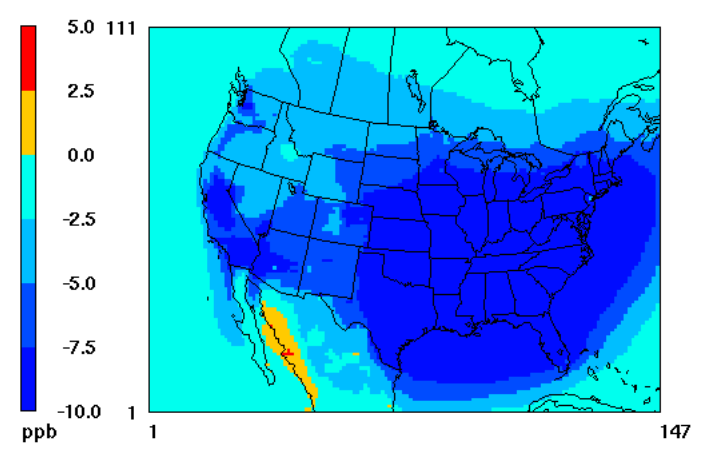

(d)

Fig. 5. (a) Three - summer - average maximum $8 \mathrm{hr}$ ozone concentrations in historic years. (b) Changes in concentrations under the impact of climate change and emission controls. (c) Changes in concentrations under the impact of climate change alone. (d) Changes in concentrations under the impact of emission changes alone.

(np: 2001 emission inventory and 2050 meteorology)

\subsection{Air quality}

\subsubsection{Model evaluation}

Model performance has been extensively evaluated for the US domain (Tagaris et al., 2007). In this study evaluation is done for both Canadian sub-regions comparing observed with predicted daily maximum eight (8) hour $\mathrm{O}_{3}\left(\mathrm{M}_{8 \mathrm{hO}}\right)$ and daily $\mathrm{PM}_{2.5}$ concentrations. Observational data for Canada has been derived from the National Air Pollution Surveillance (NAPS) Network accounting about 150 ozone and $50 \mathrm{PM}_{2.5}$ monitoring stations (http://www.etc-cte.ec.gc. $\mathrm{ca} /$ naps/index_e.html). Because of the lack of data from monitoring stations over northern Mexico, model performance in that region was not evaluated, though we did use a number of US monitors near the Mexican border in our prior evaluation.

Over both Canadian sub-regions average $\mathrm{M}_{8} \mathrm{hO}_{3}$ concentrations (Table 3 ) are overestimated since the model is biased high when ozone concentrations are very low. However, performance is very good for the days where both observed and

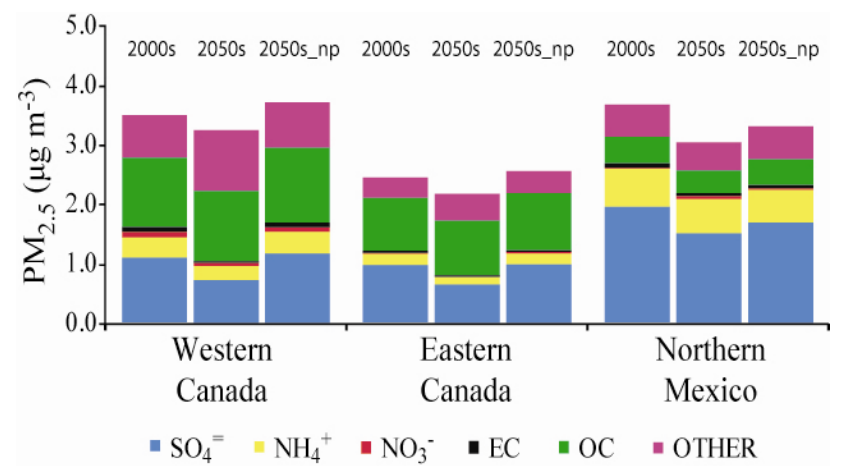

Fig. 6. $\mathrm{PM}_{2.5}$ composition for historic and future summers. (np: 2001 emission inventory and 2050 meteorology)

predicted values are greater than $35 \mathrm{ppb}$, which is around the ozone background level. $\mathrm{PM}_{2.5}$ concentrations are better simulated when lower concentrations are recorded (western Canada), but significant low bias is noted when higher values 
Table 6. Regional average $\mathrm{PM}_{2.5}$ composition (\%) for the historic and future summers using emissions projection (Future) and no emissions projection (Future_np*).

np: 2001 emission inventory and 2050 meteorology

\begin{tabular}{llllllllll}
\hline & \multicolumn{3}{c}{ Western Canada } & \multicolumn{3}{c}{ Eastern Canada } & \multicolumn{3}{c}{ Northern Mexico } \\
\hline Components (\%) & Historic & Future & Future_np & Historic & Future & Future_np & Historic & Future & Future_np \\
\hline $\mathrm{SO}_{4}^{=}$ & 31 & 23 & 32 & 39 & 31 & 38 & 53 & 50 & 52 \\
$\mathrm{NH}_{4}^{+}$ & 10 & 7 & 10 & 7 & 6 & 7 & 17 & 19 & 17 \\
$\mathrm{NO}_{3}^{-}$ & 3 & 1 & 2 & 1 & 0 & 1 & 1 & 2 & 0 \\
$\mathrm{EC}$ & 2 & 2 & 2 & 2 & 1 & 2 & 2 & 1 & 2 \\
OC & 34 & 36 & 34 & 37 & 42 & 38 & 12 & 13 & 13 \\
OTHER & 20 & 31 & 20 & 14 & 20 & 14 & 15 & 15 & 16 \\
\hline
\end{tabular}
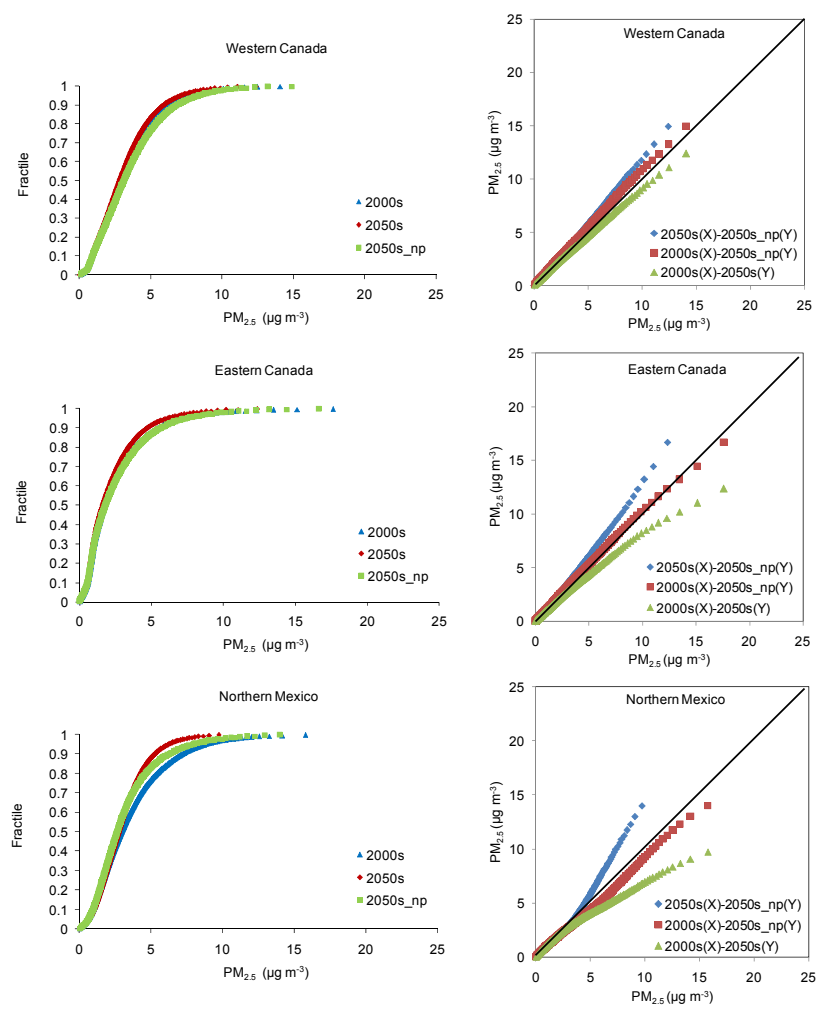

(a)

(b)

Fig. 7. Daily average $\mathrm{PM}_{2.5}$ concentration cumulative distribution function (CDF) plots (a) for historic and future summers and the correlation (b) between the different examined cases.

(np: 2001 emission inventory and 2050 meteorology) are observed. This is due to the representation of secondary organic aerosol (SOA) formation in the CMAQ. The current chemical mechanism neglects isoprene as a SOA precursor and the effect of $\mathrm{NO}_{\mathrm{x}}$ on SOA yield, along with the lower yields and higher vapor pressures in CMAQ leading to discrepancies between the predicted and observed $\mathrm{PM}_{2.5}$ concentrations.

\subsubsection{Ozone}

The impact of climate change alone and the combined effect of climate and emissions changes on $\mathrm{M} \mathrm{hO}_{3}$ are illustrated in Fig. 3a. Under the impact of climate change alone the average $\mathrm{M}_{8} \mathrm{hO}_{3}$ concentrations are estimated to be $0.1 \mathrm{ppb}$ higher $(0.1 \%)$ over western Canada, $0.6 \mathrm{ppb}$ lower (2\%) over eastern Canada and $0.5 \mathrm{ppb}$ higher $(1 \%)$ over northern Mexico (Fig. 3, Table 4) for the projections used in this study. More days when $\mathrm{M}^{8} \mathrm{hO}_{3}$ concentrations exceed the new US National Ambient Air Quality Standard of $0.075 \mathrm{ppm}$ (http://epa.gov/air/criteria.html) are forecast in all sub-regions examined and there is an increase in the peak value over Canada (Table 5). Global climate change combined with the projected emissions are calculated to reduce the atmospheric pollutant concentrations. Average $\mathrm{M} 8 \mathrm{hO}_{3}$ concentrations are estimated to be 3 ppb lower (6\%) over western Canada, 3 ppb lower (8\%) over eastern Canada and 2 ppb lower (4\%) over northern Mexico (Fig. 3, Table 4) while the days where $\mathrm{M} 8 \mathrm{hO}_{3}$ concentrations are over $75 \mathrm{ppb}$ will be significantly lower (Table 5). No significant interannual variability for regional average $\mathrm{M} \mathrm{hO} \mathrm{H}_{3}$ concentrations is noticed for both historic and future periods. The interanual variability is more pronounced for the number of days where $\mathrm{M} 8 \mathrm{hO}_{3}$ concentrations exceed $75 \mathrm{ppb}$ as well as the peak value per region (Table 5). Interestingly, although future emissions over northern Mexico are projected higher, pollutant concentrations are forecast to be lower. This is caused by the large reduction in US emissions which affect pollutant concentrations over Mexico (Figures are presented in auxiliary materials). Both Canadian sub-regions are simulated to 


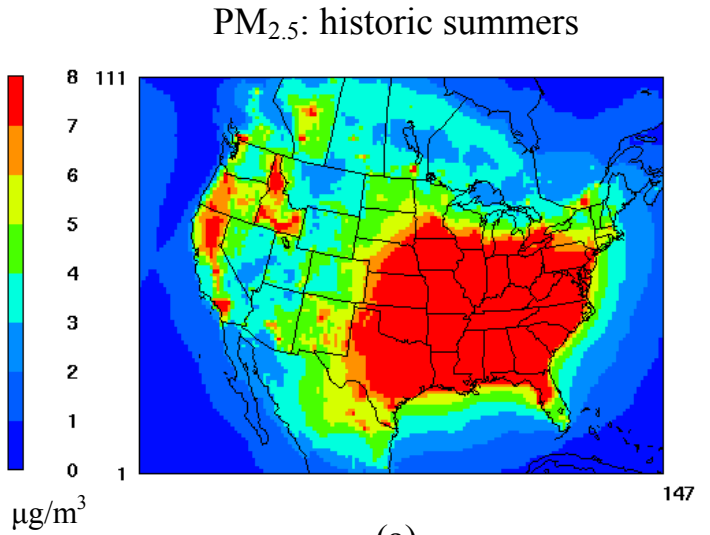

(a)

$\mathrm{PM}_{2.5}$ : future_np summers - historic summers

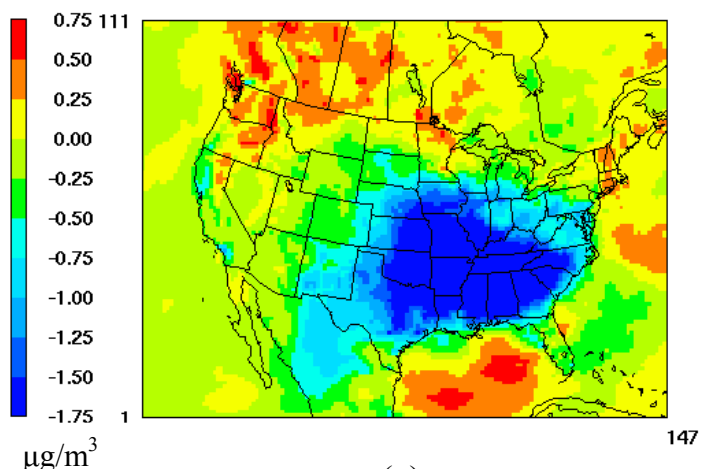

(c)
$\mathrm{PM}_{2.5}$ : future summers - historic summers

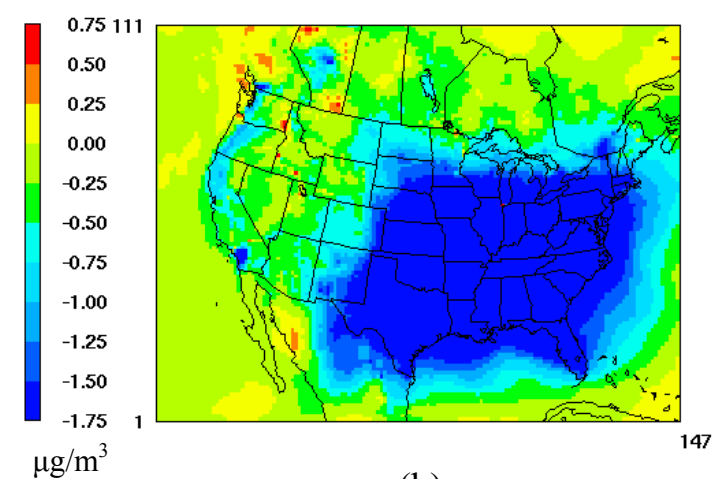

(b)

$\mathrm{PM}_{2.5}$ : future summers - future_np summers

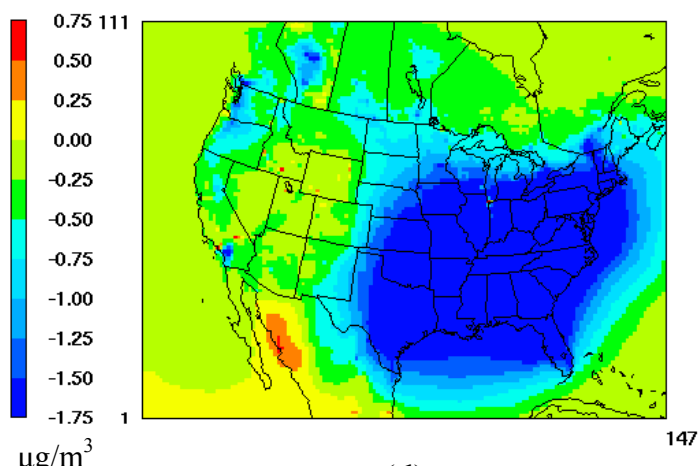

(d)

Fig. 8. (a) Three - summer - average $\mathrm{PM}_{2.5}$ concentrations in historic years. (b) Changes in concentrations under the impact of climate change and emission controls. (c) Changes in concentrations under the impact of climate change alone. (d) Changes in concentrations under the impact of emission changes alone.

(np: 2001 emission inventory and 2050 meteorology)

have lower future $\mathrm{M} \mathrm{hO}_{3}$ concentrations due to emissions reduction (2050s) shown by their Cumulative Distribution Functions (CDFs) (Fig. 4). Significant reductions are expected for the concentrations above $50 \mathrm{ppb}$, especially over eastern Canada. The same trend is found for $\mathrm{M} \mathrm{hO}_{3}$ concentrations over northern Mexico with significant reductions in concentrations above $60 \mathrm{ppb}$.

Here, boundary conditions for both historic and future periods are kept the same due to uncertainties in future global changes. Setting varying boundary conditions affect our ability to isolate the impacts of regional climate and emissions changes. Further, calculations were repeated excluding five grid cells deep of the outer perimeter of modeling domain (Giorgi and Bates, 1989), with negligible change. Regional average concentrations are similar since the winds typically come from the west well away from the land.

Over Canadian sub-regions, typical $\mathrm{M}_{8} \mathrm{hO}_{3}$ concentrations are calculated to be between 30 and $50 \mathrm{ppb}$ (Fig. 5a). This is in agreement with results from GCMs (e.g. Wu et al., 2007; Zeng et al., 2008). Climate change alone is simulated to increase $\mathrm{M} 8 \mathrm{hO}_{3}$ concentrations up to $1 \mathrm{ppb}$ in the center of Canada but a reduction of up to $2 \mathrm{ppb}$ is estimated for the rest of Canada (Fig. 5c). Emission controls are expected to reduce $\mathrm{M} 8 \mathrm{hO}_{3}$ concentrations up to $5 \mathrm{ppb}$ in both Canadian sub-regions (Fig. 5d). The combined effect of climate change and emissions changes is also found to reduce $\mathrm{M} \mathrm{hO}_{3}$ concentrations (up to $5 \mathrm{ppb}$ ) in both Canadian subregions (Fig. 5b). Over northern Mexico, the highest forecast $\mathrm{M} 8 \mathrm{hO}_{3}$ concentrations are calculated between 50 and $60 \mathrm{ppb}$ near the US border (Fig. 5a). Climate change alone is simulated to increase $\mathrm{M} 8 \mathrm{hO}_{3}$ concentrations up to $4 \mathrm{ppb}$ in the east but to decrease it up to $3 \mathrm{ppb}$ in the west (Fig. 5c). Emissions changes are expected to reduce $\mathrm{M}_{8} \mathrm{hO}_{3}$ concentrations up to $5 \mathrm{ppb}$ near the US border while it is expected to increase up to $5 \mathrm{ppb}$ on the west coast due to emission increases (Fig. 5d). The combined effect of climate change and emission changes are found to reduce $\mathrm{M} 8 \mathrm{hO}_{3}$ concentrations up to $5 \mathrm{ppb}$ in the majority of the region expect the east part 
where an increase up to $2 \mathrm{ppb}$ is predicted. (Fig. 5b).

\subsubsection{Particulate matter}

Global climate change alone has a significant effect on future summer $\mathrm{PM}_{2.5}$ concentrations over western and eastern Canada and northern Mexico as compared to $\mathrm{O}_{3}$, as changes in temperature and precipitation impact gas phase partitioning and wet deposition of particulate matter along with changes in mixing height and wind speed. More days where $\mathrm{PM}_{2.5}$ concentrations are over $15 \mu \mathrm{g} / \mathrm{m}^{3}$ over western Canada have been found but less over eastern Canada and northern Mexico, following the same trend in the peak values (Table 5). Average $\mathrm{PM}_{2.5}$ concentrations are estimated to be $0.3 \mu \mathrm{g} / \mathrm{m}^{3}$ higher $(8 \%)$ over western Canada, $0.1 \mu \mathrm{g} / \mathrm{m}^{3}$ higher (3\%) over eastern Canada and $0.4 \mu \mathrm{g} / \mathrm{m}^{3}$ lower (11\%) over northern Mexico (Fig. 3, Table 4) for the projections used in this study. These changes come mainly in $\mathrm{SO}_{4}^{=}$and OC over Canada (western Canada: $\mathrm{SO}_{4}^{=} 0.1 \mu \mathrm{g} / \mathrm{m}^{3}$ higher (12\%), OC: $0.1 \mu \mathrm{g} / \mathrm{m}^{3}$ higher (7\%), eastern Canada: $\mathrm{SO}_{4}^{=}$ $0.01 \mu \mathrm{g} / \mathrm{m}^{3}$ higher $(0.6 \%)$, OC: $0.06 \mu \mathrm{g} / \mathrm{m}^{3}$ higher $(6 \%)$ ) and from $\mathrm{SO}_{4}^{=}$over northern Mexico $\left(0.3 \mu \mathrm{g} / \mathrm{m}^{3}\right.$ lower (14\%)). $\mathrm{PM}_{2.5}$ composition will be slightly different due to climate change alone (Fig. 6, Table 6) suggesting that processes affect the $\mathrm{PM}_{2.5}$ species similarly (e.g., precipitation and dispersion). This is in agreement with Dawson et al. (2007) where they found that wind speed, mixing height, precipitation and humidity have potentially major effects on $\mathrm{PM}_{2.5}$ during summers. Global climate change combined with the projected emission changes is simulated to reduce the atmospheric pollutant concentrations. The number of days where $\mathrm{PM}_{2.5}$ concentrations exceed $15 \mu \mathrm{g} / \mathrm{m}^{3}$ is estimated to be substantially lower in all sub-regions along with the reduction in the peak values, but significant interannual variability has been found (Table 5). Average $\mathrm{PM}_{2.5}$ concentrations are estimated to be $0.2 \mu \mathrm{g} / \mathrm{m}^{3}$ lower (5\%) over western Canada, $0.3 \mu \mathrm{g} / \mathrm{m}^{3}$ lower $(11 \%$ ) over eastern Canada (Fig. 3, Table 4). $\mathrm{PM}_{2.5}$ composition is calculated to be significantly modified setting OC as the dominant component followed by sulfate (Table 6). Over northern Mexico, average $\mathrm{PM}_{2.5}$ concentrations are estimated to be $0.6 \mu \mathrm{g} / \mathrm{m}^{3}$ lower (17\%) (Fig. 3, Table 4). No significant change in $\mathrm{PM}_{2.5}$ composition is expected with sulfate to be the dominant component (about $50 \%$ ) (Table 6). Although there is no change in the lower $\mathrm{PM}_{2.5}$ concentrations (i.e., below $7 \mu \mathrm{g} / \mathrm{m}^{3}$ ) there are significant reductions in the higher levels in eastern Canada and northern Mexico when climate change and emissions projection are considered (Fig. 7). Interannual variability for regional average $\mathrm{PM}_{2.5}$ concentrations is more pronounced compared to $\mathrm{M} 8 \mathrm{hO}_{3}$ concentrations for both historic and future periods following the variability in precipitation.

Spatial distribution plots for average $\mathrm{PM}_{2.5}$ concentrations for historic years and the changes caused by climate and emission projection are presented in Fig. 8. Over the majority of both Canadian sub-regions average $\mathrm{PM}_{2.5}$ concen- trations are calculated between 2 and $5 \mu \mathrm{g} / \mathrm{m}^{3}$ (Fig. 8a). Climate change alone is simulated to increase $\mathrm{PM}_{2.5}$ concentrations up to $0.5 \mu \mathrm{g} / \mathrm{m}^{3}$ in the majority of Canadian subregions except the east where a decrease up to $0.5 \mu \mathrm{g} / \mathrm{m}^{3}$ is estimated (Fig. 8c). Emissions projection is expected to reduce $\mathrm{PM}_{2.5}$ concentrations up to $0.5 \mu \mathrm{g} / \mathrm{m}^{3}$ in the major part of both Canadian sub-regions, but there are small areas with reductions up to $1.5 \mu \mathrm{g} / \mathrm{m}^{3}$ (Fig. 8d). The combined effect of climate change and emissions projection is estimated to reduce $\mathrm{PM}_{2.5}$ concentrations up to $1 \mu \mathrm{g} / \mathrm{m}^{3}$ in both Canadian sub-regions but there are small areas where increase up to $0.5 \mu \mathrm{g} / \mathrm{m}^{3}$ is projected (Fig. 8b). Over Northern Mexico average $\mathrm{PM}_{2.5}$ concentrations are simulated higher in the northeast part with average concentrations up to $8 \mu \mathrm{g} / \mathrm{m}^{3}$ (Fig. 8a). Climate change alone is calculated to decrease $\mathrm{PM}_{2.5}$ concentrations up to $1 \mu \mathrm{g} / \mathrm{m}^{3}$ in the central part (Fig. 8c). Emissions projection is expected to reduce $\mathrm{PM}_{2.5}$ concentrations up to $1 \mu \mathrm{g} / \mathrm{m}^{3}$ near US borders while an increase up to $0.75 \mu \mathrm{g} / \mathrm{m}^{3}$ is expected in the west coast (Fig. 8d). The combined effect of climate change and emissions projection is estimate to reduce $\mathrm{PM}_{2.5}$ concentrations up to $1.75 \mu \mathrm{g} / \mathrm{m}^{3}$ in the north eastern region close to US borders while small increases are expected in the west (Fig. 8b).

Comparing the effects caused by climate and emission changes between the sub-regions examined here and the US sub-regions (Tagaris et al., 2007) it is revealed that climate change alone is not expected to significantly modify summer $\mathrm{M}^{8} \mathrm{hO} 3$ concentrations over Canadian, Mexican and US sub-regions. The effect of climate change on $\mathrm{PM}_{2.5}$ concentrations is expected to reduce summer concentrations over US and Mexico, they are more important over the Plains, Midwest and Southeast US sub-regions and Northern Mexico where significant reductions are expected in $\mathrm{PM}_{2.5}$ levels, but over both Canadian sub-regions small increases are forecast. The combined effect of climate change and projected emissions changes are simulated to reduce $\mathrm{M} 8 \mathrm{hO}_{3}$ and $\mathrm{PM}_{2.5}$ concentrations over Canadian and Mexican subregions, but this reduction is much smaller than the reduction simulated for the US sub-regions due to the projected greater emissions reductions in the latter.

\section{Conclusions}

Global climate change impacts on air quality over western and eastern Canada and northern Mexico are simulated to change future summer average $\mathrm{PM}_{2.5}$ concentrations but have little impact on average $\mathrm{O}_{3}$ levels for the projections used in this study, although changes in the higher concentrations are more pronounced. Global climate change combined with projected emission changes is simulated to reduce pollutants concentrations in all examined sub-regions. One of the most important findings of this study is that although future emissions over northern Mexico are projected to be higher, future pollutant concentrations are not as reductions in the 
US provide benefits to the south. Climate change alone is found to slightly modify $\mathrm{PM}_{2.5}$ composition while the combined effect of climate and emissions changes is forecast to change aerosol composition over Canadian sub-regions as OC becomes more dominant followed by sulfate. Over northern Mexico sulfate is simulated to continue to be the dominant $\mathrm{PM}_{2.5}$ component.

Acknowledgements. This work was supported by US EPA Science To Achieve Results (STAR) grants: RD83096001, RD82897602, RD83183801 and RD83107601. The views expressed in this paper are those of the authors and do not necessarily reflect the views or policies of the EPA. We would like to acknowledge Loretta Mickley from Harvard University for the GISS simulations, L. Ruby Leung from Pacific Northwest National Laboratory for MM5 data, Yongato Hu and Sun-Kyoung (Helena) Parker for their assistance and suggestions.

Edited by: A. Nenes

\section{References}

Binkowski, F. S. and Roselle, S. J.: Models-3 Community Multiscale Air Quality (CMAQ) model aerosol component 1. Model description, J. Geophys. Res., 108(D6), 4183, doi:10.1029/2001JD001409, 2003.

Dawson J. P, Adams, P. J., and Pandis, S. N.: Sensitivity of $\mathrm{PM}_{2.5}$ to climate in the Eastern US: a modeling case study, Atmos. Chem. Phys., 7, 4295-4309, 2007,

http://www.atmos-chem-phys.net/7/4295/2007/.

Dentener, F., Stevenson, D., Ellingsen, K., Van Noije, T., Scultze, M. et al.: The global atmospheric environment for the next generation, Environ. Sci. Technol.,40, 3586-3594, 2006.

Giorgi F. and Bates, G. T. : The climatological skill of a regional model over complex terrain, Month. Weather Rev., 117(11), 2325-2347, 1989.

Grell, G., Dudhia, J., and Stauffer, D. R.: A description of the fifth generation Penn State/NCAR mesoscale model (MM5), NCAR Tech. Note, NCAR/TN-398+STR, Natl. Center for Atmos. Res., Boulder, Colorado, 1994.

Gustafson Jr., W. I. and Leung, L. R.: Regional downscaling for air quality assessment. A reasonable proposition?, B. Am. Meteorol. Soc., 2007, 1215-1227, 2007.

Hogrefe, C., Lynn, B., Civerolo, K., Ku, J-Y., Rosenthal, J., Rosenzweig, C., Goldberg, R., Gaffin, S., Knowlton, K., and Kinney, P. L.: Simulating changes in regional air pollution over the eastern United States due to changes in global and regional climate and emissions, J. Geophy. Res., 109, D22301, doi:10.1029/2004JD004690, 2004.
IPCC (Intergovernmental Panel on Climate Change): Emissions Scenarios, Cambridge University Press, Cambridge, UK, 2000.

Knowlton, K., Rosenthal, J. E., Hogrefe, C., Lynn, B., Gaffin, S., Goldberg, R., Rosenzweig, C., Civerolo, K., Ku, J. Y., and Kinney, P. L.: Assessing ozone related health impacts under a changing climate, Environ. Health Perspect., 112(115), p. 1557, 2004.

Langner, J., Bergstrom, R., and Foltescu, V.: Impact of climate change on surface ozone and deposition of sulphur and nitrogen in Europe, Atmos. Environ., 39, 1129-1141, 2005.

Leung, L. R. and Gustafson Jr., W. I.: Potential regional climate and implications to US air quality, Geophys. Res. Lett., 32, L16711, doi:10.1029/2005GL022911, 2005.

Mickley, L. J., Jacobs, D. J., Field, B. D., and Rind, D.: Effects of future climate change on regional air pollution episodes in the United States, Geophys. Res. Lett.,31, L24103, doi:10.1029/2004GL021216, 2004.

Murazaki, K. and Hess, P.: How does climate change contribute to surface ozone change over the United States, J. Geophys. Res., 111, D05301, doi:10.1029/2005JD005873, 2006.

Rind, D., Lerner, J., Shah, K., and Suozzo, R.: Use of on line tracers as a diagnostic tool in general circulation model development: 2 . Transport between the troposphere and the stratosphere, J. Geophys. Res., 104, 9123-9139, 1999.

Tagaris, E., Manomaiphiboon, K., Liao, K. J., Leung, L. R., Woo, J. H., He, S., Amar, P., and Russell, A. G.: Impacts of global climate change and emissions on regional ozone and fine particulate matter concentrations over the United States, J. Geophys. Res., 112, D14312, doi:10.1029/2006JD008262, 2007.

Woo, J. H., He, S., Amar, P., Tagaris, E., Manomaiphiboon, K., Liao, K. J., and Russell, A. G.: Development of MidCentury Anthropogenic Emissions Inventory in Support of Regional Air Quality Modeling under Influence of Climate Change, 15th Annual Emission Inventory Conference Reinventing Inventories New Ideas in New Orleans 16-18 May, New Orleans, Louisiana, available at: http://www.epa.gov/ttn/chief/ conference/ei15/session4/woo2.pdf, 2006.

Woo, J.H., He, S., Tagaris, E., Liao, K.J., Manomaiphiboon, K., Amar, P., and Russell, A.G.: Development of North American Emission Inventories for Air Quality Modeling under Climate Change, J. Air Waste Manage. Assoc., J. Air Waste Manage. Assoc., in press, 2008.

Wu, S., Mickley, L. J., Jacob, D. J., Logan, J. A., Yantosca, R. M., and Rind D.: Why are there large differences between models in global budgets of tropospheric ozone?, J. Geophys. Res., 112, D05302, doi:10.1029/2006JD007801, 2007.

Zeng, C., Pyle, J. A., and Young P. J.: Impact of climate change on tropospheric ozone and its global budget, Atmos. Chem. Phys., 8, 369-387, 2008, http://www.atmos-chem-phys.net/8/369/2008/. 